\title{
Politics and Identity in an EFL Class: Did You Say a Suicide
}

\section{Bomb Attack?}

\author{
Nizar Kamal Ibrahim ${ }^{1 *}$ \\ ${ }^{1}$ Lebanese University, Faculty of Education, Beirut, Lebanon \\ *Nizar Kamal Ibrahim, E-mail: pronizar.ki@gmail.com
}

\begin{abstract}
This article explores the possibility of critical analysis of terrorist suicide bomb attacks in an EFL critical literacy course. It reports on a part of a broader study that explored how 24 EFL high school Lebanese students were engaged in critical literacy activities during the whole 2013-2014 academic year. Most participants belonged to Lebanese communities that support Hezbollah, a Lebanese political party that plays an important role in the regional politics of the Middle East. The school was also located in an area dwelled mainly by supporters of this party. The participants wrote critical analysis essays about a double suicide bomb attack that took place close to their school, were involved in a focus group and were interviewed, all of which constituted the data. The study revealed that critical literacy events around hot political topics of significance to the students stimulate the students' desires to learn the target language and give rise to complex discourses that reflect their multiple identities. In addition, critical analysis involved students in reconsidering their ideas and their ways of reacting to critical militarized political events.
\end{abstract}

\section{Keywords}

politics in an EFL high school class, critical literacy around terrorism, sensitive political issues in an EFL literacy course

\section{Introduction}

In the last three decades, language and literacy education have increasingly been influenced by concerns with equity, ideology, and the sociopolitical/socioeconomic distribution of power. This influence has manifested itself in critical approaches to language education in both first and second language teaching (Hammond \& Macken-horarik, 1999; Luke \& Dooley, 2011). These approaches, one of which is critical literacy, have spread in the West, in Latin America and in few African and Asian countries (Luke \& Dooley, 2011; Pennycook, 2001). However, EFL/ESL programs and curricula in many parts of the world still adopt the technical view of language instruction and focus on market skills, ignoring the socioeconomic and sociopolitical circumstances in which language teaching is embedded (Ko \& Wang, 2012; Wallace, 2003; Zhang, 2009). This deprives students from opportunities to read, write, listen, and speak about significant sociopolitical and socioeconomic matters that impact their 
lives (Bahruth, 2004; Frey \& Fisher, 2015; McLaughlin \& DeVoogd, 2004). In Lebanon as well as in most countries in the Middle East, resistance to critical literacy is not restricted to language education, but it characterizes the educational process in general and is linked to broader ideological and political circumstances. This gives rise to the following questions:

(1) Can critical literacy practices in settings where militarized political and sectarian conflicts are at their peak initiate EFL students into critical reflection and analysis of the sociopolitical conditions of their lives?

(2) How does an EFL critical literacy course function in settings where religious ideologies dominate?

(3) How do the students' religious, political and social identities affect, and are affected by their critical analysis of the political violence in their communities?

(4) What characterizes the students' discourses that emerge in EFL critical literacy tasks in such settings?

\section{Literature Review}

"We live in a time that is so brutal and so unforgiving that we must always ask ourselves if we are dreaming” (McLaren, 2005, p. xxvii). "Global integration is proceeding alongside sociocultural disintegration, the resurgence of various separatisms, and international terrorism” (Benhabib, 2002, p. viii, as cited in Hull, Zacher, \& Hibbert, 2009, p. 119). The Middle East is one of many regions in the world that suffer from poverty, dictatorial regimes, strong separatism movements, terrorism by both militant groups and by governmental agencies, occupations both old and new, dismantlement of states, and fragmented citizenship. In this context, in which terrorism has escalated dangerously since 2010 in the Middle East, including Lebanon, education in general and second language education in particular is still disconnected from the students' lives and adopts a technical view of teaching. In other parts of the world, some of which witness stability at many levels, an increasing awareness of the political nature of education expresses itself in critical literacy approaches in both institutionalized and non-institutionalized settings (e.g., Benesche, 1993; Canagarajah, 2004; Connolly, 2013; Huang, 2011; Luke, A., Luke, C., \& Graham, 2007; Luke \& Dooley, 2011; Shor \& Pari, 2000; Morgan, 1997; Wallace, 2003). This is premised on the view that "education should nurture a critical spirit in students in order to examine how the world can be freer, more just, and more democratic. If schools and universities were to play their social role in pursuing such goals, the pedagogical vision and practices should empower students to become politically interested and mobilized to achieve greater social equality across lines of race, gender and class” (Giroux, 2007, p. 195).

Ironically, critical approaches to education, including EFL education, are strongly resisted in most Middle Eastern countries where they are mostly needed. If these countries are to take the routes of peace, stability, and development, education must inspire a restless and questioning mind that explores the reasons of the unimaginable and ugly political, economic, and social scenes that have become a part of what we view daily and examine possibilities for change. This concern for change has been taken up 
by Critical approaches to TESOL that started emerging in the 1980s, informed by sociological, ethnographic, and applied linguistics research on language policy and education for second language learners; this encompasses ongoing exploration of the international spread of English, examination of the social and political implications of second language teaching, and research on educational equity for linguistic and cultural minorities (Luke \& Dooley, 2011; Pennycook, 1999). These efforts have culminated in a vision for critical applied linguistics developed by Pennycook (1999, 2001). “Taking up Poster's (1989) terms, critical applied linguistics is an approach to language-related questions that springs from an assumption that we live amid a world of pain and that applied linguistics may have an important role in either the production or the alleviation of some of that pain. But it is also a view that resides not merely upon the alleviation of pain, but also the possibility of change" (Pennycook, 2001, p. 52). This vision has led to many directions in both research and pedagogy in all the domains of applied linguistics.

\subsection{Critical Pedagogy and Critical Applied Linguistics}

One major orientation in critical work is critical pedagogy, grounded in Freire's thought. Freire (1993) argues that human's ontological vocation is to realize his full humanity, which, according to him, is obstructed by oppression and domination. He contends that the unfinished character of mankind and the social, economic and political conditions that govern the life of the human beings constitute a reality that can and should be transformed. Thus, Freire (1993) believes that critical educative practice should be an ongoing activity that aims to help people recognize the causes of oppression so that they take transformative action and "create a new situation that makes possible the pursuit of a fuller humanity” (p. 38). In Pedagogy of Freedom, a book published after his death, Freire (2001) explains that a critical educator conceives of teaching as a form of intervention in the world, specifically because it is a human experience implicated in the wider political, social, and economic context.

Freire's philosophy has informed many aspects of critical work in TESOL. Essentially, both critical pedagogy and critical applied linguistics share the view that language education is political in nature. This has led to some common premises between critical pedagogy and critical applied linguistics, including the idea of problematization inspired by Freire's notion of problem-posing education, the idea of praxis which refers to the interconnection between theory and practice, and the idea of transformative pedagogies. The common vision that both critical pedagogy and critical applied linguistics share is best illustrated in the following excerpt:

On the one hand, then, critical approaches to TESOL must necessarily take up certain positions and stances: the view of language or of language learning cannot be an autonomous one that backs away from connecting language to broader political concerns; the understanding of education must see pedagogy as a question of cultural politics; and the focus on politics must be accountable to broader political and ethical visions that put inequality, oppression, and compassion to the forefront. On the other hand, it is important to avoid a narrow and normative vision of how those politics work. (Pennycook, 1999, p. 333) 
While this view of the role of politics in critical applied linguistics is encompassing many directions in research and pedagogy, highlighting possibilities for transformation is inspired by Freire's thoughts. Both critical pedagogy and critical applied linguistics share the idea that any possibility for transformation requires a systematic conceptualization of how people can act differently (e.g., Benish, 1993; Crookes, 2010; Freire, 2001; Giroux, 1983; Norton \& Toohey, 2011; Pennycook, 1999). This transformative pedagogy is based on the assumption that although individuals are to a certain degree constrained by ideologies and discourses, they also possess a degree of freedom (Freire, 1970, 1993; Giroux, 1983, Pennycook, 1999; Shor, 2009). Pennycook (1999) stipulates that any critical approach should work at reconciling degrees of constraint with degrees of freedom and should engage with the students' desires, investments, and histories. This pedagogy of engagement can empower students and make them agentive in the process of change within a vision of the preferred future, the notion of which helps us shape a restrained and plural view of the possible alternatives to the status quo (Pennycook, 2001).

However, critical applied linguistics as well as other critical work in education do not only draw on critical pedagogy, but they are also grounded in other theoretical orientations that do not espouse the term "critical”, (e.g., feminism, racism, identity theories, queer theory, multiculturalism) (Pennycook, 2001; Shor, 2009). For example, Pennycook (2001) stipulates that critical applied linguistics is not an amalgam of other critical domains such as critical linguistics, Critical Discourse Analysis (CDA), critical language awareness, critical pedagogy, critical sociolinguistics, and critical literacy. He argues: “... critical applied linguistics is far more than the addition of a critical dimension to applied linguistics; rather, it opens up a whole new array of questions and concerns, issues such as identity, sexuality, or the reproduction of Otherness that have hitherto not been considered as concerns related to applied linguistics” (2001, p. 8). This view emphasizes the study of how the multiple contexts of language learning (social, political, economic, cultural, or physical) provide learners with either enhancing or inhibiting opportunities for learning, based on an assumption that social relations are problematic (Pennycook, 1999). From this perspective, critical applied linguistics has to address questions of inequality, injustice, rights and wrongs by going beyond mere correlations between language and society in its exploration of language in social contexts (Crookes, 2010; Pennycook, 2001). It should instead raise "more critical questions to do with access, power, disparity, desire, difference, and resistance. It also insists on a historical understanding of how social relations came to be the way they are” (Pennycook, 2001, p. 5).

The new conceptualization of L2 research and pedagogy guided by a critical orientation to applied linguistics has given rise to many studies, focusing on the relationship between language learning on one hand and identity, gender, ethnicity, discrimination, etc. on the other hand in multi-cultural contexts, (e.g., Block, 2015; Canagarajah, 2004; Fernsten, 2008; Flowerdew \& Wang, 2015; Ibrahim, 1999; Kubota, 2004; Kubota \& Lin, 2006; Matsuda, 2015; Morgan, 2004; Sunderland, 2004; Trofimovich \& Turuševa, 2015). 
Thus, critical approaches to TESOL have explored the interrelationship between language learning and many aspects of identity formation. The issues addressed by these studies have emerged from the contexts of their research sites and have been sensitive to the local concerns of their participants and to other contextual conditions (Luke, 2000). This was an essential consideration in choosing the topic and constructing the research questions in the present study, which capitalized on the reflexivity of the critical reorientation of applied linguistics. This reorientation, which aims to analyze how multiple forms of identity intersect in complex ways and how culture or discourse may play important roles in promoting the ways of understanding, reproducing, or changing difference by shifting the focus away from considering only material conditions of inequality (Pennycook, 1999), guided the present study. The sensitivity to the sociopolitical context of the participants directed the study to explore not merely how language learning and multiple forms of identity interrelate, but to investigate how an EFL class can provide students with opportunities to reflect on critical political events, during which multiple, competing identities emerge. This is based on the responsibility of TESOL educators to engage with a problematizing stance that always confronts them with questions about the ethics and politics of what they do (Pennycook, 1999). In addition, the study is grounded in a balance between the Freirian approach and the post-structuralist approach to critical literacy, which, according to Pennycook (2001), is a constitutive component of critical applied linguistics. As will be evident in the description of instruction, the study used both approaches in a complementary way.

\subsection{Critical Literacy}

As part of critical applied linguistics, critical literacy has been extended to ESL/EFL classrooms. Three main orientations in critical literacy can be noted: the Freirian approach, the text analytic approach, and the poststructuralist approach.

\subsubsection{The Freirian Approach}

The Freirian approach to critical literacy aims to question power relations, discourses and identities in an unfinished, unjust and inhumane world. Shor (2009) explains that the political, economic, and social circumstances that shape our communities and that condition our relationship to the globe make it necessary to question the many myths engendered in the rhetoric of religious, political, and economic leaders and in the language used in the textbooks. Freire and Macedo (1987) theorize that students should "read the word and the world", i.e., learning how to read and write should be related to the students' experiences and lives in order to dissect the local and global conditions that shape them in the way they are. In this approach, teachers problematize issues that arise from texts, during which students name, reflect and act (Bishop, 2014; Freire, 1998; Ibrahim, 2008; Wink, 2000).

Although Freire's thoughts run through all approaches to critical literacy by degrees, they feature most strongly in explicitly political approaches to critical pedagogy (Luke \& Dooley, 2011). According to Luke and Dooley (2011), this approach focuses on ideology critique which starts from the students' lived experiences and key problems in order to deconstruct the dominant systems that create and maintain inequality. In regular classes, mostly in American schools, dialogic pedagogy has led to a 
focus on student voice and democratic interaction around issues of moral, social and cultural significance (Luke \& Dooley, 2011; Pennycook, 2001). This was transferred to ESL school and university classes, in which critical work starts with a focus on community relations or political events and does not end with agentive, alternative analysis (Luke \& Dooley, 2011).

\subsubsection{The Text Analytic Approach}

Some critics of critical pedagogy in Australia and Britain have raised the concern that critical pedagogy overlooks ESL students' need to understand the complex text structures and discourse of various genres and to master them (Halliday \& Martin, 1995; as cited in Luke \& Dooley, 2011). Luke and Dooley (2011) argue that an exclusive focus on voice or ideology critique does not lead to equitable access to the functions of texts, which represents an essential component to redistributive justice. Pennycook (1999, p. 338) explains:

Many Australian educators argue for providing students with access to the different genres, drawing on propositions by Delpit (1988) that well-intentioned, white liberal pedagogies that back away from overtly teaching "the culture of power" do not help African Americans and on similar propositions by Australian genre theorists (Christie, 1996; Hammond \& Macken-horarik, 1999). They contend, therefore, that students need to master generic structures before they can engage in critical literacy and that skipping that overt instructional process in favor of a general injunction to be critical does a disservice to students from disadvantaged backgrounds.

Many practitioners and researchers who adopt the CLA perspective borrow from systemic functional grammar to examine the ideological positioning of texts. For example, Janks (1997) suggests looking for the following in a textual analysis:

(1) Lexicalisation;

(2) Patterns of transitivity;

(3) The use of active and passive voice;

(4) The use of nominalization;

(5) Choices of mood;

(6) Choices of modality or polarity;

(7) The thematic structure of the text;

(8) The information focus;

(9) Cohesion devices (p. 335).

Research guided by the text analytic approaches focus on how language choices are driven by social practices, assumptions and beliefs (e.g., Janks, 2005; Ko, 2013; Ko \& Wang, 2012; Wallace, 2003).

\subsubsection{The Post-Structuralist Approach}

The post-structuralist perspective views language and the activities associated with it as socially contextualized (Missen \& Morgan, 2006). According to Missen and Morgan (2006), texts, whatever their nature, are permeated with ideology and play an essential role in the construction of our identities. From the post-structuralist educators' viewpoint, both texts and the practice of reading are socially and 
ideologically constructed (Huang, 2011), because any literacy act is qualified by assumptions, beliefs, values, expectations, and related conceptual material that occur in particular socio-historical circumstances (Gregory \& Cahill, 2009). Thus, from a post-structuralist perspective, "literacy education is ultimately concerned with giving students an understanding of textuality (i.e., of the way texts work)" (Missen \& Morgan, 2006). Post-structuralist literacy educators bracket and disrupt the texts' "natural" given or taken-for-granted authoritative status in institutional and everyday contexts (Luke \& Dooley, 2011). They aim to deconstruct texts in order to reveal how they position the readers (Huang, 2011; Janks, 2000), so they propose to approach texts from different angles. The following questions illustrate this approach:

(1) Who/What is represented in this text?

(2) Who/What is absent or not represented?

(3) What is the author trying to accomplish with this text?

(4) For whom was this text written?

(5) Who stands to benefit/be hurt from this text?

(6) How is language used in specific ways to convey ideas in this text?

(7) How do other texts/authors represent this idea?

(8) How could this text be rewritten to convey a different idea/representation (Stevens \& Bean, 2007, p. $11)$ ?

Thus, poststructuralist educators give students the opportunity and training to question the authors' stances, to critically analyze the motives of texts, to explore the under-represented or marginalized views, and to examine texts from different perspectives.

\section{The Theoretical Position of the Study}

Although the three approaches to critical literacy differ in their foci, they share the view that educators should be committed to a just society and democratic education that considers students as participants in the educational process, that gives students every possibility and resource to question and interrogate the world for its injustices, and that empowers students to become agents in realizing the dream of a luxurious, non-discriminatory, equitable and peaceful life for everyone; this view is adopted in the present study, taking up Jank's (2000) call for using the different approaches of critical literacy interdependently. The study also capitalizes on Pennycook's assumption that "a central issue always concerns how the classroom, text, or conversation is related to broader social cultural and political relations” (1999, p. 51). In her argument for critical English for academic purposes, Benesch (1993) critiques the pragmatists' concern with developing the students' skills and their avoidance of the questions of power, justice, and difference, offering the following suggestion:

We could, as Boyer (1990) suggests, negotiate academic curricula responsive to urgent social, economic, and political issues, rather than serving one that is so narrowly focused on career preparation: the aim of education is not only to prepare students for productive careers, but also to enable them to Published by SCHOLINK INC. 
live lives of dignity and purpose; not only to generate new knowledge, but to channel the knowledge to humane ends; not merely to study government, but to help shape citizenry that can promote public good. Thus, higher education's vision must be widened if the nation is to be rescued from problems that threaten to diminish permanently the quality of life (p. 714).

Actually, Benesch's vision, which can, and should be, promoted at all educational levels (Gregory \& Cahill, 2009; Share, 2010), foregrounds the present study.

\section{The Study}

In the 2013-2014 academic years, a high school EFL instructor and I cooperated in implementing a critical literacy course at a Lebanese public school in the Southern Suburb of Beirut. The 24 grade 11 male students who took the course were engaged in critical literacy activities throughout the whole academic year. They performed different critical literacy tasks based on a model that consists of the following four phases: Accessing the text, direct instruction, problematizing the text, and going beyond the text (Ibrahim, 2015). The students' ages ranged between 15 and 16 years. Many of them came from low-income families. The instructor and I decided to use the school textbook titled "Themes" as well as other supplemental material relevant to the themes in the textbook. This facilitated access to the research site because the school manager encouraged the idea as long as we use the textbook.

\subsection{The Context}

The research site in the Southern Suburb of Beirut is an area mainly populated by supporters of Hezbollah, a Lebanese political party that played a major role in resisting the Israeli occupation of Lebanon and that has recently been implicated in the Syrian armed conflict. Some participants were even members in this party. A few of them, however, were not supporters of Hezbollah. Hezbollah's emergence in the 1980s in response to the Israeli invasion of Lebanon, its resistance of the invasion, its involvement in Lebanese local politics, and its participation in the war in Syria form a part of the complex political setting in Lebanon. Actually, this complex setting resulted from old religious and sectarian conflicts that have accumulated over time and that took different directions at different historical points (see Ibrahim, 2015) for more details. The Lebanese civil war that lasted for three decades ended in 1990. However, it turned into political conflicts in which different religious groups have been trying to maintain their interests. The conflict between the two major Islamic sects in Lebanon, Sunnis and Shiites, was the latest twist in the political turmoil that the country has been witnessing amidst political hardships in many parts of the Middle East that turned into military struggles in some countries. The situation was even more complicated by the intervention of Al-Qaeda and ISIS, who targeted civilian areas dwelled mainly by supporters of Hezbollah with more than ten terrorist attacks during the last four years. These attacks killed and injured hundreds of people. Some of the victims were relatives of some participants in the study, during which two simultaneous suicide bomb attacks hit an embassy very close to the research site, causing many casualties. Fortunately, however, the school was not physically impacted by the explosions, and none of the students got killed 
or injured. It was a critical moment in the students' lives, a moment that cannot be ignored by any critical language teacher. The event constituted a major opportunity for critical reflection and analysis of the political conditions that circumscribed the explosions.

\subsection{Instruction}

Data in this research report relate to two units of instruction that were selected from ten instructional units implemented in the study. In these two units, the instructor made use of critical troublesome political events that affected the participants tremendously, in order to make them reflect critically on reasons and consequences of armed political strife. It happened that right before the two suicide bomb attacks took place close to the school, students had finished a sequence of instruction that involved them in analyzing how the language used by news reporters promotes an interested narrative of the armed conflict between the two Muslim sects, Sunnis and Alawites, that was taking place during the study in the Lebanese Northern city, Tripoli. In this sequence, the students read the school-mandated short story "The sniper" at home and discussed it in class. The instructor made use of this story to guide a discussion about the causes and consequences of wars. She asked students to give examples from real-life events in Lebanon. Then, students were asked to read three articles about snipers in Tripoli. The articles were selected from different newspapers that have different political affiliations. The students had to copy the main information in the three articles into a table in order to compare the language used by the authors. Then, the teacher asked the following questions to involve students in critical text analysis:

(1) How do the three articles differ in their presentation of the events?

(2) Which one is more biased? Why?

(3) Has your background affected your choice? How?

(4) Can the other articles be biased? Why?

(5) How can you determine the more biased article?

(6) What textual ideas and language support your choices?

The two suicide bombers from Al-Qaeda had exploded themselves close to the school when the teacher was about to start a new unit of instruction, using a text from the school textbook about Bill Gates. In this unit, the students were supposed to conduct a discussion around the following questions:

(1) What does the information in the text show?

(2) What does the text want us to believe?

(3) What things does the text not tell about?

(4) How in your opinion has Bill Gates become a millionaire?

(5) At home, search for stories about Bill Gates on the internet. Bring these stories that challenge the dominant one. Read some of them in class and discuss the hidden narrative of how Bill Gates became a millionaire.

The critical explosion event could not be ignored by any critical approach to EFL, so the instructor and I decided to replace the Bill Gate lesson with another one about this event. The students were asked to 
select one of the most moving images about the two explosions from the social media and comment on it. This set the ground for a class discussion about the topic, after which students reflected on the event in a journal entry. Then, students used their entries in writing a critical analysis essay about their own reactions to the event, the motives and the goals of the suicide bombers, and possible solutions to the problem.

\subsection{Data}

Data were collected from multiple sources. Two focus groups with the participants purported to explore their attitudes towards critical literacy. A critical analysis essay required students to analyze many political, social and psychological aspects connected with the terrorist explosions. A structured interview with three students sought a deeper understanding of their responses in the critical analysis essay. An interview with the teacher aimed to seek her view of the class dynamics during the students' interaction around the topic of the explosions. These data were categorized into themes. The categories were revised several times until each set of data was linked coherently under each theme, and this constituted the basis for analysis. The participants were assigned fake names.

\section{Analysis and Discussion}

When we decided to implement a critical literacy lesson about the double suicide bomb attack, we were afraid that it might backfire. However, this "tragic scene”, as one participant described it, was transformed into some critical language tasks through which students could describe, express emotions, reflect, analyze and critique. More importantly, it was a critical literacy lesson that exemplifies how teachers can bring what scares students, what affects them emotionally, physically, and intellectually, and what dominates their reactions and thoughts into the language classroom, with the aim of starting a transformative process. So how did students engage in critical analysis about such an event and what did their responses reflect about the potentiality of transformative pedagogy and about the students' potentials to use such critical educational moments to develop mature sociopolitical perspectives?

Data from the students' responses, from their interviews, and from the interview with the teacher reveal how critical language tasks around a significant event in the students' lives could stimulate their desires to use the foreign language in expressing original thoughts and feelings. The data also show that having a sensitive political topic in a critical EFL literacy class gave rise to the students' discourses in which multiple identities were evident. They indicate that the students' critical discourses interacted with their belief systems and with the discourses of their local communities in complex ways.

\subsection{Vivid Scenes}

The students' responses conveyed a mixture of fear, anxiety, sorrow, anguish, panic, worry about relatives, making choices, analysis, and judgments. Morad captured the moment as follows:

"At the $3^{\text {rd }}$ period, in the history class, at 9:30 a.m., a big explosion happened ... It was too loud. I thought that it's near to us. All the class begin asking: “What is this? Where is (it)?” Many questions in our mind that we don't have its answers. When I saw the Black smoke rising in the air after the bomb, 
(I thought) this explosion was caused by man-made device. (We were all) afraid and begin calling but no network was. When I know that the explosion was at Iranian cultural center in Beer Hassan ... beside my grandfather house, I (worried that) my grandfather was walking there or any of my family and friends was there".

Morad's reflection illustrates how most students felt at that "time of death in this black life", as Hameed worded it. It shows creativity in the student's use of language to talk about his emotions and worries. This creativity is evident in the descriptions that many students gave of the minute of the explosion. For example, Fadol who was at home, located in the very street where the explosion took place, stated: "When the floor started dancing, I thought that the street becomes like destruction and no one ... is still alive". Issam "imagined that the doomsday began. (His) brain gave (him) bad views (about) the place (of the explosion)". These "views" were detailed by Awad as follows:

"Human remains, (a) massive number of people crying, running, (among them the) injured. The ground covered by the blood of innocent people ... going to their work, and students ... going to their schools. What do you think: massive destruction ... damaged buildings, totally destroyed cars, fire fighters and Red Cross teams".

These excerpts express the students' fears, worries and thoughts in authentic language that draws the critical situation with its many details. Reflecting on this critical situation about which the students were highly concerned made them give vivid and varied descriptions of the scene. In these descriptions, the students used what they possessed of the language to convey their original ideas and feelings in unique and creative ways. In an interview, the class instructor confirmed these conclusions. She said: The students enjoyed talking and writing about the explosion a lot. Because we were next to the explosion site, they reflected smoothly about it. Because the students live in the southern district of Beirut, most of them have heard or witnessed the explosions. Some of them even have relatives who were injured or killed in the explosions. They had the chance to express their ideas and feelings about something that concerns them and that has frightened them for a long time. It is something they have experienced in their daily life, (which) facilitated the task. They had enough background about what was going on, so (their descriptions of their experiences were) fluent, smooth and sincere. The language was not a barrier. They revealed their political and religious perspectives. Through that, we started talking about whose responsibility it is.

These remarks imply that writing critically about a political event of immediate relevance to the students provides them with opportunities to pull all their language resources together to reflect their passions, ideologies and identities. Norton (1997) explains: "identity relates to desire-the desire for recognition, the desire for affiliation, and the desire for security and safety. Such desires, West asserts, cannot be separated from the distribution of material resources in society. People who have access to a wide range of resources in a society will have access to power and privilege, which will in turn influence how they understand their relationship to the world and their possibilities for the future" (p. 410). This definition that encompasses the various complex dimensions of identity helps in interpreting 
the students' reflections about the explosion event. These reflections reveal how the students' desires (desires for security, for affiliation, for the expression of fears and passions, etc.) interrelate in strong ways with their desire to use the target language. Language in such a context carries some aspects of the students' identities and voices. Many students agreed with their instructor's observations about their desires to write and speak when they are so connected to the topic. For instance, Jameel “... still (remembers) how exciting the activity about the explosions was”, because he expressed (his) feelings and thoughts about something that frightened him for long. He also liked it when he used the social network and picked up a picture "that really reflects how (he) thinks about the suicide bombers who ruined our lives”. Jameel explained that writing, reading and speaking about significant matters created interest in language activities. The participants' comments imply that involving students in discussing political issues in a language class stimulates their desires to use the language in exchanging their political views. This runs counter to the fear that many language teachers have towards raising such issues in their classes (Beck, 2005).

\subsection{Authentic Discourse}

The unique descriptions of the moment of explosion are the manifestations of how each student interacted with his particular circumstances. For instance, Abdallah, who was at home in the very place of the explosion, said:

"It was a new feeling for me. I didn’t know that will come a day I will be that afraid. I get into the safest room, act nature because my sister was afraid, so I make her come down. It was danger, since there was a fire and we cannot turn it off".

Abdallah's discourse depicts a situation in which emotions, though intense, cannot reign. His responsibility towards his sister forced him to hide his emotions and to take action. His language corresponds to his situation which differed from those of his classmates who were at school at that time. Although the school was in the vicinity of the explosion, it was not critically close. This critical difference of the place and the context of the students are reflected in the emotions and ideas the participants expressed and in the discourse they used to express them. A comparison between Abdalla's and Naeem's scenes shows how a critical task derived from the lives of the students leads to authentic and varied discourse based on each student's context and reaction. Naeem's description was as follows: “I ... stood still. I wasn’t able to react normally. It was a gloomy, trifling feeling. No one can simply control his reaction at a similar moment. It was a stunning moment that can't be described”. While both Abdallah and Naeem expressed strong emotions, Abdallah's rhetoric was permeated with expressions of action and problem-solving (going to the safest room, acting normally to calm the sister, etc.). Despite his intense fear caused by the serious life threat, his language was dominated by the sense of responsibility that controlled his emotions. However, Naeem's discourse gave way to strong emotional reactions that happened to be by "standing still". Thus, reflecting on a critical event made students use authentic discourse that reflected each one's distinct ways of interacting with his particular situation. The responses of other students support this inference. Other comments show the chaos that naturally 
takes place after explosions. Awad and Hameed gave some descriptive details about the chaotic moment during which students were shouting, running, asking for permission to leave, etc. ... Awaad saw "(some classmates) crying with tears of fear and other is angry because he was unable to communicate with his family”. Thus, many students used authentic language in expressing their unique reactions to the critical explosion event. Evidently, their responses are characterized with vivid description, diverse perspectives from which the scene was depicted, and a rich language that reflected each one's situation in interesting ways.

\subsection{An Emerging Critical Discourse}

In addition, the students' reflections demonstrate the use of a critical discourse in reflecting on their emotions and in expressing empathy with the victims of the explosion. Some students started using critical language like the term "oppressed" to describe the victims, to analyze how the criminals think, and to analyze why the casualties are considered victims. For instance, Shahab felt sorrowful about these casualties "because it is not their fault". Both Fadol and Shahab described those victims as "oppressed". Shahab elaborated: "They are oppressed by the people who think that they are smart because they send bombed cars to kill innocent people”. These responses indicate that the students started using critical terminology to interpret the mentality of the suicide bombers and to describe their victims. This critical discourse conveys a mixture of fear about one's life and about relatives as well as empathy with the casualties. The following excerpt by Zaher testifies to that effect:

There is a great difference between the moment of (thinking about) death and the moment you feel that death is approaching you closer and closer. The feeling of weakness and distraction is the only thing that controls your actions whenever you are in danger. Simply it's the human nature... The same feeling is repeating itself at every moment an explosion happens, fear from death last in concentration ... When I realize that (my family and relatives are fine), I quite understand that there are many innocent people were killed accidently due to a suicide bomber act.

This excerpt shows how the student used the emerging critical discourse to interpret his emotional reactions and to describe how these emotions progressed from worries about one's life, to worries about affinities, to empathy with the victims. This emerging critical discourse is illustrated in the student's analysis of how fear from death naturally leads to a dominant concern about one's existence and how once this concern is reduced, other worries and feelings rise to the surface.

\subsection{Action, Reaction or Critical Reflection?}

In their retrospections, the students provided seemingly contradictory descriptions of their behaviors after the explosion. On one hand, many talked about the chaos that occurred, and on the other hand, they mentioned the importance of acting rationally. This may demonstrate that writing reflectively about the explosion made students recognize the importance to better manage their reactions, through balancing between "(being) terrified and nervous" on one hand and "(staying) calm" on the other, as Jameel clarified. The reflective thinking about how students should behave in difficult circumstances is illustrated in some responses. For example, Zaher stressed that "in a moment like this every person 
must stay calm in order to understand what is happening", and "(think) logically (to take) right decisions", as Firas elaborated. One of these decisions, according to Issam, "(is) to be strong” and to face the "serious conflict". These responses imply that contemplating the critical explosion event resulted in the expression of specific ways to take control of the situation. Issam even started speculating about the next political and military moves. The students' ideas about controlling one's reactions and reasoning about the situation seem to contrast, to a certain degree, with the shock and chaos depicted in the previous part. It is possible that the participants started reflecting on their initial reactions after they had passed the shock. Also, the reflective writing task might have made them rationalize about these reactions and recognize the need to take control of the situation. Their ideas about "staying calm", "being strong" and "thinking logically" indicate that having the explosion as a topic for critical reflection in a language class gives students a chance to think through different ways of managing their reactions in such dangerous circumstances. Their reflections show their awareness of the importance of managing their emotions and acting rationally.

\subsection{Rationalizing Versus Irrationality: Is Analysis Possible?}

In addition to being imbued with emotional reactions and with reflective thoughts, the students' responses demonstrate an approach of reasoning about the motives of the suicide bombers, but the irrationality of such acts seems to present some of them with a block. Thus, astonishment is evident in some participants' attempts to analyze the motives of these people. This is mostly reflected in the following questions:

(1) How dare such kind of a person decide to end people's life?

(2) What kind of goals a person like this can establish?

(3) Other than death is there no place or time for dialogue?

(4) Is death or fear the only language these people know and deal with (Zaher)?

(5) How (does the terrorist) have the courage to kill himself in people-girls or boys, babies or adult, with us or against us (Abdallah)?

(6) Why you are bomb yourself in our country? You thought you will become happy when you bomb yourself (Firas)?

These questions imply two competing but parallel tracks of reasoning about the motives of suicide bombers: astonishment on one hand and repeated attempts to understand the motives behind bombarding populated areas on the other. This questioning links the suicidal action with possible goals that the terrorists might have. It also displays a wonder at why other options to deal with the conflict were not considered by the suicide bombers. Zaher, for instance, extrapolated that "such people believe that "violence may be a mean to resolve all conflicts and clashes". This indicates an attempt to put forth a logical interpretation of the motives of such people. However, it seems that this was hindered by the irrationality of bombarding civilian areas, and this is supported by the idea that the students could not put themselves in the shoes of these bombers and find a logical explanation of their acts because, as Zaher declared, the participants themselves "are not killers". So, judgments that suicide bombers "are 
criminals", "are not human beings", "have lost their senses", "are like animals in the forest" characterize many responses. The inability to comprehend the drives behind such acts is worded nicely in Zaher's conclusion that "it is beyond a civilized person's capacity to understand how (suicide bombers) can kill innocent people. This is not heroism. This is cowardice”.

The irrational and complex drives of exploding civilian areas and the difficulty of reasoning about such drives seem to lead students to make judgments. Hazem illustrates how the incompatibility between reason and the acts of terrorists lead to judgmental thinking. He drew an ideal image of human beings who have "a hundred way" of solving problems, based on which he concluded that "coward people always (have) one way to solve (problems): bombs". This image becomes clearer when the student makes the following juxtaposition: "Resorting to violence is a way of life in the forest not for humans who have the mind for facilitate their life". This encompasses a systematic approach to analyze the drives of violence based on an ideal view of the task of human beings: creating better life conditions. In this contrast, Hazem reveals a vision which he uses to evaluate the degree to which someone is a human being. This vision is conceptualized by Freire (1993) as "human's Ontological vocation” to realize his full humanity. This humanity, according to Freire, is obstructed by oppression and domination. Actually, some students thought of the suicide bombers' acts as oppression and domination and saw in these acts hindrance to the development of humanity. While this insightful and systematic analysis points to some students' intellectual curiosity to diagnose the ills of the world (Freire, 1993), this curiosity, which becomes what Freire (2001) calls "epistemological curiosity" when one is increasingly critical in his learning, seems to vary among different students. The understandable tendencies to judge and stereotype the Islamist militants as barbaric characterize many responses, but these tendencies are accompanied by some reasoning about their motives and consequences.

Despite the difficulty that many participants found in reasoning about the motives of the suicide bombers, some reflections embody a sociopolitical understanding of this phenomenon. This understanding is clearly entailed in Naeem's idea that "the political situation plays a big role in stimulating those who explode their selves”. Zaher, whose astonishment at the barbarity of suicide bombers has been reported in the previous parts, specified this political situation in response to the following question in a follow up interview: "Islamist militant groups adopt religious ideologies that promote violence. What are the reasons for adopting such views?” He explained:

First adapting terrorist ideas from extremists is due to the misunderstanding of Islam from a side and the lack of civil belonging to a homeland from the other side. Terrorists (adopt) such ... beliefs because they feel oppressed from certain ... dictatorial regimes that deals with such cases throughout violence and their response takes a revengeful form. They believe that throughout their actions they can spread their beliefs by fear and force.

Any organization that has a religious background is not a civil one and it does not follow the civilian laws. Their bylaws depend on religious views and according to these standards they judge and rule.... Ibn Roshd, the philosopher Qortoba once said, "If you want to control the mind of an illiterate, you Published by SCHOLINK INC. 
have to cover every bad thing with a religious cover".

This lengthy answer demonstrates a sophisticated understanding of the political conditions in the Middle East that led to terrorism. It reflects an insightful idea about how religion might create identities that exclude the other and how the weak belongingness to one entity and the absence of a common identity cause violence. These insights are embodied in Jameel's idea that the different religious groups and sociopolitical communities aggravate the conflict and maintain a split society or "dispersion", as Hazem stressed. These intricate analyses of the motives behind political and religious violence show an understanding of the importance of shared identities and interests in maintaining a coherent society and of how critical differences might be divisive. The complex construction of multiple identities and their roles in shaping socioeconomic and sociopolitical patterns that are conducive either to difference or to solidarity (Morgan, 1997; Pennycook, 2001; Shor, 2009) are entailed in the students' sophisticated analyses. In addition, other participants shed light on other dimensions of the motives of suicide bombers. For instance, Hameed stated that these bombers believe that exploding non-military areas is a way to prevent the enemy from attacking them, and consequently it is a self-defense strategy. The student continued that this should be expected because in armed conflicts, every side uses what is deemed appropriate in attacking the other side. This student stands out among his classmates in providing a military interpretation of the event that reflects different desires that are part of our identities (Norton \& Toohey, 2011). However, Hameed could not find a logical political one. In his attempt to present a coherent political explanation congruent with the illogicality of the suicide bombers' act, he maintained that "those terrorists are dolls moved by other forces". Awaad agreed elaborating that "as a child who can easily be interested in playing a game, terrorists make a brain wash for teenagers and force them to kill innocent people”. These varied explanations sketch a number of sociopolitical and psychological dimensions of the reasons that make someone become a suicide bomber. This shows the potential of critical literacy to make students express and reflect on their political views. Through critical reflection, the students' political views can be broadened so that they become principled. As Freire (2001) argues, problematizing the students' experiences and the relationship of these experiences to the world increasingly challenges them to construct and reconstruct their views. As a result, students engage in a dialogue, the process of which brings about new challenges and leads to new understandings. This critical dialogue, Freire (1993) speculates, will gradually commit students to the cause of justice.

\subsection{Social Discourse in the Students' Responses}

The students' answers vary in the degree to which they challenge stereotypical ideas regarding whether or not the suicide bombers achieved their goals. Only a few participants stated that the terrorists achieved some goals. For instance, Hameed claimed that these goals are to hit the center of security of Hezbollah, to put pressure on Hezbollah and to change the attitude of Hezbollah supporters. Based on that, the student maintained that although the main goal was not realized, the terrorists "achieved specific points". According to him, killing children and innocent people exerts a physical and 
psychological impact. This impact was specified in Hazem's speculation that suicide bombers aim "to make our mind sore and sad. So, we stop thinking to do and (develop)”. These responses are coherent with the two participants' overall analysis. Hameed's idea is congruent with what he speculated about the goals of the terrorists, and Hazem's thought is consistent with his vision about the task of human beings discussed in the previous part. Both participants reflected deep insights about the consequences of armed conflicts. However, many other participants gave typical responses as to whether the bombers achieved their goals, influenced by the discourses that were circulating in their communities.

Many participants asserted that terrorists could not reach their goals because "the real goal is to face the enemy and not killing innocent civilians”, as Khalid explained. Shahab stated: “These explosions are set to kill some officials in Hezbollah and they can't reach them when they try so they explode the car in any area”. These responses reflect a cliché that was promoted by the media every time an explosion happened. It seems that many participants submitted to this rhetoric and did not challenge it. Jameel's responses and clarifications upon answering follow up questions reveal his contradictions when these clichés were challenged. In his reflective writing task, the participant stated: "the bombers do not fulfill the goals they are done for, because their war is between the Army that they face, not the poor people that ... don't participate in the war”. In a follow up interview, Jameel was asked the following questions: "What are their goals? If one of their goals is killing people, haven't they achieved this goal?” Jameel provided the following answer: "their goal is to build their state with their religion and policy. They kill people that they hate them and they do not believe in their country and policy”. This last idea of killing people contradicts the previous one about not achieving the goals.

Jameel's contemplations illustrate the discourse of many of his classmates, which seem to mirror, to various degrees, the dominant rhetoric in the media and in the social networks of their communities. A critical literacy teacher might probe students to contemplate the contradictions in their discourses and in those of their communities (Bishop, 2014), based on a critical vision that rejects from the outset, the liberal humanist view of individuals as completely independent, free, creative entities (Pennycook, 1999). As Pennycook argues, "Thought, movement, and speech are always constrained in multiple ways” (1999, p. 335). However, this does not mean that people are slaves to ideologies or prisoners of discursive practices, and considering them as such is over deterministic and leaves no possibility for individual agency to act upon and change the human conditions (Pennycook, 1999, 2001). Although individuals are to a certain degree constrained by ideologies and discourses, they also possess a degree of freedom, both of which should be reconciled in any critical approach. With this in mind, critical literacy events empower students and make them aware of their agentive roles in the course of events. It helps them imagine a better state of affairs and devote their efforts to realize it (Shor, 2009).

\subsection{The Religious Rhetoric}

Religious explanations were advanced by some participants to present a stance and to interpret some dimensions of the bombers acts. For instance, Naeem highlighted the following belief:

The goals of these explosions are not fulfilled, and they will never be, since death with respect to us

Published by SCHOLINK INC. 
and to our people is dignity, death is not the end, it is just a new start between the hands of God. These explosions can just lead for more faith and more believe.

This discourse clearly points out the religious bond that holds a community together and shapes the social boundaries between one community and another. The student's representation of his community is reflected in the pronouns he uses "us", "we" and "our people". This religious rhetoric contributes strongly to creating the imagined identities that set different communities apart. Death, according to this student, means a new life, which is guaranteed to his community members just because they belong to this religious sect. This implies that other people who belong to other religions or sects will not have this status. Naeem's ideas illustrate how the religious ideology of a certain community circulates in the rhetoric of the community members and shapes a distinct group identity that is imagined. However, people might possess multiple identities, some of which cross the boundaries of ethnic, religious, and other ideological groups (Bishop, 2014; Ibrahim, 1999; Morgan, 1997; Norton \& Toohey, 2011). In his reaction to the explosion, Hameed revealed multiple identities, one of which is affiliated with his religious group and another that is shared with people in general. Hameed said:

I don't think about my mother because I know she was in village also brothers in school at Shoiefet. But my brain go to near girls' school, since they are a strategic point in affecting people and Shia, and we are all know what women and girls mean to us.

In his reference to "people and Shia", Hameed conceptualizes the concern for women and children as something common to humanity, and he makes a reference to his religious community as a distinct group that shares with other groups these common values. Hameed's response reflects a possibility to emphasize the ties that bind us (Hull, Zacher, \& Hibbert, 2009). As Hull, Zacher and Hibbert explain, everyone possesses many affiliations, and choosing any of them in a particular context depends on the sociopolitical circumstances, personal beliefs, and the purpose of the agent. It is important for political, social, religious, and educational practices and discourses to nurture in people a vision that balances between legitimate differences on one hand and universality on the other (Hull, Zacher, \& Hibbert, 2009). However, one identity might dominate people’s perception of themselves and of issues they face at a particular time, in a particular context. The strength of one's affiliation with one or more of the groups in which he is a member depends to some degree on the social discourse that he adopts (Hawkins \& Norton, 2009). If one of the imagined identities dominates and leads to opposing and alienating values (Hull, Zacher, \& Hibbert, 2009), which might be true with religious and non-religious communities, discriminatory language starts to emerge in the discourse of the community members. Actually, the instructor mentioned that in the class discussion about the explosions, her students used discriminatory language. For instance, some said that they are patriotic more than other groups and that some other groups hate them. This language was not clearly present in their written reflections. As Shor (2009) maintains, discourse is not destiny. We can reshape our rhetoric and our identities to become more encompassing of the human interests, if we wish to do so. It seems that many participants started developing a less divisive discourse during the various reflective tasks they performed. This is Published by SCHOLINK INC. 
confirmed by the instructor's remark that the students started questioning their ideas and reduced their discriminatory language after their engagement in critical literacy events. She stated: "we started interrogating is Hezbollah right? Is our religion right? We have started to go deep and referring to documents and documented events”. It seems that writing reflectively about different aspects of the explosion event as a follow up on their initial discussion of their reactions to it made students change their discourses, which became more rational.

The religious logic is also used by the suicide bombers in justifying their acts, but with a different line of thought than the one presented by the participants. This difference made many participants deny the terrorists' affiliation to any "true religion". Shahab argued: "these suicide bombers are people who don't have any type of religion, every one who is against them they kill him and cut his head”. Saeed agreed, saying that "a true religion” calls for "love and peace, not violence and brutality". Zaher stressed that the suicide bombers misunderstand Islam. Morad specified this misunderstanding in that "some people told them that if they kill the Shia, they will go paradise and they will have marriage with the prettiest girls in paradise, but in our religion ... God says that suicide is something that take you to hell”. These arguments indicate a denunciation of violence and a call for accepting the other. But isn't this rhetoric dependent on the Fatwas of religious authorities, i.e., binding statements that religious authorities issue? All religions derive their value systems from holy sources as interpreted by religious leaders. Thus, believers do not question these values based on reasoning that takes the interests of human beings into account. In other words, this rhetoric of love and peace might be transformed into a rhetoric of violence if any threat to religious values or ideologies is perceived by a certain community or by its religious leaders. The students' responses demonstrate that their desires to be part of a certain religious group based on a belief system that cannot be subject to reason are, to a great extent, constituted through discourse. Thus, the indoctrinating discourses that religious leaders use to pass their ideologies to their communities and the nature of these ideologies play important roles in either broadening the different identities of the members of their communities or in narrowing these identities so that they become more exclusive of the common interests of human beings. Critical literacy, which should be based on respect for the human desires as long as these desires are not harmful, induces people to question the values and discourses that create boundaries among different groups. It helps them see that people everywhere share many common interests and that what sets different groups apart is not, and should not be divisive. As Shor (2009) explains, critical literacy equips students with the conceptual tools to question the many myths that impact our lives tremendously. It seems that the participants in this study started rethinking their ideas about the "other".

Some participants portrayed the following dilemma: religion tells us that we should not kill, but we should do so if we are threatened. For example, Jameel theorized that "the bombers are people who don't have any feeling against the children and don't have any religion, since in my religion or any religion you must not kill people unless they are terrorists”. This denial of the humanity and of any religious affiliation of suicide bombers because of their terrorist acts is accompanied by a religious 
justification of killing in case of life-threat. Actually, this justification of killing in self-defense is advanced by most individuals and sociopolitical groups-not only religious people. The conflict between the denunciation of terrorism and the call for killing in self-defense reflects the complexity of the political situation in which security is in danger. This danger makes reasoning about what motivates suicide bomb attacks difficult. It is the eminent danger that makes contemplating the social, economic and political reasons of the phenomenon of terrorism in the world overshadowed by stigmatizing the other. Can this stigmatizing be a subject for reflection? In the follow up interview, Jameel was probed to contemplate his ideas in response to the following questions:

Don't all wars cause casualties among civilians, including children? What is the difference between terrorists on one hand and other groups and countries that commit war crimes on the other? Isn't fighting and killing the terrorists considered a part of the warfare that causes casualties?

The student responded as follows:

Yes, in all wars there are huge number of dead people, there is no difference between terrorist and the countries that fight each other. Both harm humanity. Terrorists don't believe in God. They don't have religion so they kill kids, women, men and older people so that they can build their Islamic state that they believe in it. Those terrorists kill kids on purpose. They believe that they will meet the prophet and have lunch with him.

It can be noticed that the student showed a broad concern for humanity by considering all wars, including terrorism, as harmful to humanity. However, he insisted on justifying the fight against the Islamist militants, reasoning that they are terrorists who do not show any pity for old people, women, and children. While the student's reasoning is justified, engaging him in critical reflection might make him examine different alternatives of dealing with military conflicts, including terrorism. Thus, in a critical literacy class that addresses local or universal issues systematically, students might be involved in multiple reflective tasks in order to deepen their analysis and to make them ponder their contradictory ideas.

\subsection{Foreseeing the Dead-End}

Many students expressed human feelings and denounced violence as a means to resolve conflicts. Khalid explained that violence is "a bad solution" and as Naeem and Jameel emphasized, weapons should never be used to resolve conflicts or to achieve political goals. According to Jameel and Saeed, to have such political goals, people should be respectful and wise "instead of (using) violence and brutality”, as Saeed asserted. This reflects an interesting view of the role of politics: respect for humanity. Saeed even linked the concept of political goals built on respect for human rights to having "true" religious beliefs. He argued: "political conflicts can be solved by ways of human thinking, not reaching in a "barbaric" way without using any human specification". Zaher shared this belief with Saeed and went further in his analysis when he wondered: "what is the profit other than the death of innocent people distributing racial and sectarian conflicts?” These comments show the students' critical analysis of how conflicts escalate, giving rise to various divisive identities. They embody a realization 
of how exclusive imagined identities lead to different forms of violence, with a dead-end. Abdallah expressed this sense beautifully: "fire on fire just will have a bigger fire". This idea was explained more concretely by Naeem who said that "violence ... would make the conflict bigger and bigger (and) will lead to more deaths". According to Naeem, this creates a "terrible" situation in which no one can live. He stated: "every side attacks the other side, making no respect for the people following them". Obviously, the complex dimensions of violent conflicts are depicted in the students' responses, and they indicate the potential to create political awareness among high school students. It seems that it is possible for a critical literacy course to initiate a discourse characterized by reasoning about the consequences of violence and about better alternatives.

\subsection{A Call for Dialogue, but with Whom?}

Hull, Zacher and Hibbert (2009) call for dialogue as the most important tool in the face of splitting differences that result from opposing and alienating values. The authors cite Appadurai (2006a) who stresses that dialogue is an obligatory path to explore our moral obligations towards others and to overcome the many fears that possess us. This, according to the researchers, should be based on a sense of belonging to the human community, which should make us constantly ask: what is it that we owe to others? Are these "global ethics" possible in the complex context of the Middle East? Do students who live amidst many fears develop this kind of thinking? Some participants called for dialogue which they viewed as instrumental in solving political conflicts. Khalid exemplifies this through his conception that people should engage in "dialogue (in order to) understand the other (so that we) reach the goals that benefit the people". Zaher argued that "in the end political goals can only be accomplished throughout dialogue and positive communication". In the follow up interview, he was asked: "What should the dialogue be about and on what basis? How could this dialogue be initiated and how can people participate in it?” The student answered: “according to this Islamic omen, Islamic organization mostly depends on violence to spread their thoughts and beliefs. Due to that, any conversation is a total waste of time. Actually, such organization must be banned”. Obviously, the complexity of a situation in which extremists reject others, based on their ideologies and identities leads to contradictory reasoning for a solution. Zaher, who explained in a previous part that terrorism came about partly in response to the oppression of dictatorial regimes and who called for dialogue, does not think that dialogue is possible with these extremists. Consequently, the solution according to him is to ban such groups, i.e., to refer to the same policies that led to their emergence in the first place. Actually, dialogue requires mutual respect and willingness to negotiate differences, which is not possible when differences are translated into militarism, but banning these groups will maintain the vicious cycle. This intricate dilemma is bound to systemic circumstances that require work at a large scale, but can a systematic critical analysis with different groups of people help in reaching a clearer idea about how to break this vicious cycle? This question is for contemplation and further research. However, Zaher's further reflection upon probing him with more questions indicates the possibility of having a discourse that gets us out of the box. In his reflections on his ideas, Zaher explained: 
Fighting poverty is the main course. Here people hold a rifle for a piece of sandwich, after that dialogue through schools and university. Lebanon needs a lot of work throughout civilian organization. There must be laws that take action efficiently on the ground in order to stop and limit religious views from spreading more and more. All the Lebanese parties must be banned and replace it with civilian political parties according to a certain law that can organize it properly.

Wishing and hoping that this barbarianism and complicated issues reaches to its maximum because people all are fed up of it. They all want in 2015 to be all one hand achieving Arabic goals.

Obviously, this excerpt entails a critical view of religion and its deterministic perspectives and links this to the difficulty of engaging in dialogues with people who hold such deterministic views. Zaher represents a distinct case in his class and he seems to possess a coherent view of the role of religion in politics. Based on that view, the participant seems to reject any role of religion in the sociopolitical life of any country. Certainly, this is contradictory with his idea about the importance of dialogue and represents a sociopolitical dilemma in the Middle East and elsewhere. The importance of critical literacy is to make people express these contradictions and subject them to analysis (Bishop, 2014; Morgan, 1997). Certainly, Zaher's critical view of religion is not adopted by many other participants, most of whom were religiously committed and based their views on religious grounds. Many of them called for dialogue. At the same time, they, like Zaher, did not think that dialogue with the suicide bombers is possible. This may reflect their desire for peace that is faced with the challenge of communicating with the opposite side.

\subsection{Hope or Despair?}

Unfortunately, many responses give the impression that the students started preparing themselves to live in turbulent situations. Some reflections include a strong and direct indication that violence and terror will characterize the scene in Lebanon. Zaher provides clear evidence to that effect in his statement: "this is Lebanon, the land of bloody conflicts that plays randomly with our destiny", and which, according to Shahab, “(is) on the edge of abyss". Awad concluded that "all this draw the picture of Lebanon nowadays and Lebanon the future”. Obviously, hopelessness characterizes these responses. This sense of hopelessness is best portrayed in the words of Morad: "Lebanon? Good Political situation? Two words cannot combine in one sentence", and in Hameed's "black life". Khalid attributed the hopeless political Lebanese situation to the idea that "the politician wants his own interest and not the public interest". However, with this sense of hopelessness, the tendency to survive in this abyss emerged in Zaher's statement that "whenever the last act of life is closer to us, the more we will starve for life”. Can critical literacy practices empower students to re-conceptualize the world as well as their roles in that world? Can such practices make students feel more hopeful and agentive in a world full of pain? As Freire argues, we do not have a choice but to engage in the struggle for a better state of affairs. The various discourses that emerged in the students' critical analysis of a life-threatening event indicate that critical literacy can play a role in the struggle for a better life. When contradictions get to the surface and are probed for more reflection, reason might take over. 


\section{Conclusion}

The data in the present study indicate that critical literacy tasks around military and political events of high significance to the students gave rise to multiple desires and identities. The desire for peace and safety, the desire for stability, the desire for development, etc. are evident in the students' responses. However, the data show that some of these desires and identities competed with each other (e.g., the desire for dialogue competed with the need for self-defense; the identification with one's religious group competed with the desire for national affiliation that encompasses other groups; the desire to analyze competed with the desire to stereotype, etc.). These competing desires and identities situated in the broader social discourses of the participants' communities were not fixed. The different critical literacy events helped the students in reflecting on their discourses and in reconsidering their beliefs. The students' reflective thoughts interacted dialectically with the social discourses of their communities in complex ways. Moreover, the different critical literacy events that gave the students opportunities to express their thoughts about their beliefs, their worries, their ideas of the "other", etc. made them use the target language in creative ways and stimulated their interests to invest in using it. These results, however, are only suggestive of the potentials of critical literacy instruction. The sociopolitical and socioeconomic nature of literacy implies that the dynamics of a critical literacy class change with time and with different groups of learners. This restricts the conclusions of the study to its participants especially that these participants are only males and belong to a specific Lebanese sociopolitical group. Thus, future research might address questions like:

(1) How would other groups (groups of a different gender; different sociopolitical groups; groups composed of different ideologies, sexes or sociopolitical affiliations), respond to critical literacy tasks, what discourses would they reveal, and what desires and identities would they manifest?

(2) Would the participants in the present study transfer their critical literacy practices to their social life and would they play any agentive role in their communities as a result of this practice?

Each of these research directions requires a different type of studies that takes into consideration its context. The last question, for instance, requires a critical ethnographic study that documents the discourses that some participants in the present study use in enacting various sociopolitical roles in their lives. Thus, the efforts to realize the vision of critical education demand the documentation of the outcomes of different literacy events in a variety of contexts. It is, as freire (2001) argues, an ongoing educative practice that evolves as the human moves forward in realizing his full humanity.

\section{References}

Bahruth, R. (2004). Critical literacy vs. reading programs: Schooling as a form of control. International Journal of Learning, 11, 509-515. Retrieved January 7, 2015, from http://ijl.cgpublisher.com

Beck, A. S. (2005). A Place for Critical Literacy. Journal of Adolescent \& Adult Literacy, 48(5), 392-400. Retrieved January, 28, 2015, from http://www.jstor.org/stable/40013804

Benesch, S. (1993). ESL, ideology, and the politics of pragmatism. TESOL Quarterly, 27(4), 705-717. 
Bishop, E. (2014). Critical literacy: Bringing theory to praxis. Journal of Curriculum Theorizing, 30(1), 51-63.

Block, D. (2015). Social class in applied linguistics. Annual Review of Applied Linguistics, 35, 1-19.

Canagarajah, S. (2004). Subversive identities, pedagogical safe houses, and critical learning. In B. Norton, \& K. Toohey (Eds.), Critical pedagogies and language learning (pp. 6-137). New York: Cambridge University Press.

Connolly, B. (2013). Theorizing creative, critical pedagogy: The art of politicized agency. Retrieved from http://www.rizoma-freireano.org/index.php/theorising-creative-critical-pedagogy

Crookes, G. (2010). The practicality and relevance of second language critical pedagogy. Language Teaching, 43(3), 333-348.

Fernsten, A. L. (2008). Writer identity and ESL learners. Journal of Adolescent \& Adult Literacy, 5(1), $44-52$.

Flowerdew, J., \& Wang, S. (2015). Identity in academic discourse. Annual Review of Applied Linguistics, 35, 81-99.

Freire, P. (1970). Pedagogy of the oppressed. New York: Continuum.

Freire, P. (1972). Education: Domestication or liberation? Prospects, 2, 173-181. Retrieved February 7 , 2013, from http://collections.infocollections.org/ukedu/en/d/Jh1825e/5.2.html

Freire, P. (1973). Education: The practice of freedom. London: Writers and Readers Publishing Cooperative.

Freire, P. (1993). Pedagogy of the city. New York, NY: Continuum.

Freire, P. (1994). Pedagogy of hope: Reliving pedagogy of the oppressed (R. R. Barr, Trans.). New York: Continuum.

Freire, P. (2001). Pedagogy of Freedom. New York: Rowman \& Littlefield.

Freire, P., \& Macedo, D. (1987). Literacy: Reading the word and the world. South Hadley, MA: Bergin \& Garvey.

Frey, N., \& Fisher, D. (2015). The role of critical literacy in citizenship. RHI Magazine. Retrieved from http://www.randomhouse.com/highschool/RHI_magazine/active_citizens/freyfisher2.html

Giroux, H. (1983). Theory and resistance in education: A pedagogy for the opposition. South Hadley, MA: Bergin Garvey.

Giroux, J. (2007). Educated hope in dark times: Critical pedagogy for social justice. Our Schools, Our Selves, 17(1), 195-202.

Gregory, A., \& Cahill, M, (2009). Constructing critical literacy: Self-reflexive ways for curriculum and pedagogy. Critical Literacy: Theories and Practices, 3(2), 6-16. Retrieved October 28, 2012, from http://scholarworks.boisestate.edu/literacy_facpubs/62/

Hammond, J., \& Macken-Horarik, M. (1999). Critical literacy: Challenges and questions for ESL classrooms. TESOL Quarterly, 33(3), 528-544. http://dx.doi.org/10.2307/3587678 
Hawkins, M., \& Norton, B. (2009). Critical language teacher education. In A. Burns, \& J. Richards (Eds.), Cambridge guide to second language teacher education (pp. 30-39). New York: Cambridge University Press.

Huang, C. (2011). Critical literacy helps wipe away the dirt on our glasses: Towards an understanding of reading as ideological practice. English Teaching: Practice and Critique, 10(1), 140-164. Retrieved December 20, 2012, from http://www.eric.ed.gov/ERICWebPortal/ERICServlet?accno= EJ935567

Huang, S. (2009). EFL reading through a critical literacy perspective. English Teaching \& Learning, 33(3), 51-93.

Huang, S. (2011). Reading "further and beyond the text": Student perspectives of critical literacy in EFL reading and writing. Journal of Adolescent \& Adult Literacy, 55(2), 145-154.

Hull, G., Zacher, J., \& Hibbert L. (2009). Youth, Risk, and Equity in a Global World. Review of Research in Education, 33, 117-159. Retrieved from http://www.jstor.org/stable/40588120

Ibrahim, A. (1999). Becoming black: Rap and hip hop, race, gender, identity and the politics of ESL learning. TESOL Quarterly, 33(3), 349-369.

Ibrahim, N. (2008). Children's literature for second language learners. Beirut: The Lebanese University.

Ibrahim, N. (2015). Critical literacy: Performance and reactions. Theory and Practices in Language Studies, 4(4), 756-764.

Janks, H. (1997). Critical discourse analysis as a research tool. Discourse: Studies in the Cultural Politics of Education, 18, 329-342.

Janks, H. (2000). Domination, access, diversity and design: A synthesis for critical literacy education. Educational Review, 52, 175-186.

Janks, H. (2005). Language and the design of texts. English Teaching: Practice and Critique, 4(3), 97-110.

Ko, M. (2013). Critical Literacy Practices in the EFL Context and the English Language Proficiency: Further Exploration. English Language Teaching, 6(11), 17-28.

Ko, M., \& Wang, T. (2012). EFL learners' critical literacy practices: A Case study of four college students in Taiwan. The Asia-Pacific Education Researcher, 22(3), 221-229. http://dx.doi.org/1007/s40299-012-0013-5

Kubota, R., \& Lin, A. (2006). Introduction. Race and TESOL: Special Issue of TESOL Quarterly, 40(6).

Kubota. (2004). Critical multiculturalism in second language education. In B. Norton, \& K. Toohey (Eds.), Critical pedagogies and language learning (pp. 30-52). New York: Cambridge University.

Luke, A. (2000). Critical literacy in Australia: A matter of context and standpoint. Journal of Adolescent \& Adult Literacy, 43, 448-461.

Luke, A., \& Dooley, K. T. (2011). Critical literacy and second language learning. In E. Hinkel (Ed.), Published by SCHOLINK INC. 
Handbook of research on second language teaching and learning (pp. 886-902). New York: Routledge.

Luke, A., Luke, C., \& Graham, W. P. (2007). Globalization, corpatism, and critical language education. International Multilingual Research Journal, 1(1), 1-13.

Matsuda, P. (2015). Identity in written discourse. Annual Review of Applied Linguistics, 35, 140-159.

McLaren, P. (2005). Preface. In P. Freire (Ed.), Teachers as cultural workers: Letters to those who dare teach (pp. xxi-xxx). Boulder: Westview Press.

McLaughlin, M., \& DeVoogd, G. (2004). Critical literacy as comprehension: Expanding reader response. Journal of Adolescent \& Adult Literacy, 48(1), 52-62. http://dx.doi.org/10.1598/ JAAL.48.1.5

Missen, R., \& Morgan, W. (2006). Critical literacy and the aesthetic: Transforming the English classroom. Urbana, IL: National Council of Teachers of English.

Morgan, B. (2004). Modals and memories: A grammar lesson on the Quebec referendum on sovereignty. In B. Norton, \& K. Toohey (Eds.), Critical pedagogies and language learning (pp. 158-178). New York: Cambridge University Press.

Morgan, W. (1997). Critical literacy in the classroom: The art of the possible. NY, NY: Routledge.

Norton, B. (1997). Language, identity and the ownership of English. TESOL Quarterly, 31(3), 409-429.

Norton, B., \& Pavlenko, A. (2004). Addressing gender in the ESL/EFL classroom. TESOL Quarterly, 38(3), 504-514.

Norton, B., \& Toohey, K. (2011). Identity, language learning, and social change. Language Teaching, 44(4), 412-446.

Norton, B., \& Vanderheyden, K. (2004). Comic book culture and second language learners. In B. Norton, \& K. Toohey (Eds.), Critical pedagogies and language learning (pp. 201-221). New York: Cambridge University Press.

Pennycook, A. (1999). Introduction: Critical approaches to TESOL. TESOL Quarterly, 33(3), 329-348.

Pennycook, A. (2001). Critical applied linguistics. Mahwah, New Jersey: Lawrence Erlbaum.

Share, J. (2010). The Earlier the Better; Expanding and Deepening Literacy with Young Children. International Critical Childhood Policy Studies, 3(1), 108-136.

Shor, I. (2009). What is critical literacy. In A. Darder, R. D. Baltodano, \& M. Torres (Eds.), The critical pedagogy reader (pp. 282-304). New York: Routledge.

Shor, I., \& Pari, P. (Eds.). (2000). Education is politics: Critical teaching across differences, postsecondary. Portsmouth: Heinemann.

Stevens, L. P., \& Bean, T. W. (2007). Critical literacy: Context, research, and practice in the K-12 classroom. Thousand Oaks, CA: Sage.

Sunderland, J. (2004). Classroom interaction, gender, and foreign language learning. In B. Norton, \& K. Toohey (Eds.), Critical pedagogies and language learning (pp. 222-241). New York: Cambridge University Press. 
Trofimovich, P., \& Turuševa, L. (2015). Ethnic identity and second language learning. Annual Review of Applied Linguistics, 35, 234-252.

Wallace, C. (2003). Critical reading in language education. New York: Palgrave Macmillan.

Wink, J. (2000). Critical pedagogy: Notes from the real world (2nd ed.). New York: Addison Wesley Longman Publishers.

Zhang, L. J. (2009). Teaching critical reading to in-service EFL teachers in Singapore. TESOL TEIS Newsletter, 24(1), 1-10. Retrieved January 9, 2012, from http://www.tesol.org/s_tesol/ article.asp?vid=167\&DID=12486\&sid=1\&cid=738\&iid=12400\&nid=3091 